(Received July 18,1983$)$

\title{
STRONG PIEZOELECTRIC ACTIVITY IN SIMULTANEOUSLY STRETCHED AND POLED POLY(VINYLIDENE FLUORIDE)
}

\author{
By Shigeru Tasaka, Katsumi Shiraishi, Kazutomo Murakami \\ and Seizo Miyata \\ (Faculty of Technology, Tokyo University of Agriculture \\ and Technology, 2-24-16, Koganei, Tokyo 184, Japan)
}

\begin{abstract}
Piezoelectric properties of Poly (vinylidene fluoride) films in stretched, annealed and poled states were investigated in terms of function of annealing conditions. With increasing the annealing temperature, a lattice spacing, $d(110,200)$, in form I crystal decreases and the crystallinity increases; however, the dipole orientation induced by the field becomes imperfect. Consequently, for the roughly packed crystal, it could be expected that poling would facilitate the dipole orientation.

From the above result, the new method of electret preparation in PVDF and its related copolymer is proposed. This method, which consists of simultaneous drawing and poling, can apply the field to necking zone where the transition of form II to form I occurs. The sample with unstable crystal structure can easily be modified to have strong piezoelectric constant $\left(d_{31} \sim 40 \mathrm{pC} / \mathrm{N}\right)$ by this method.
\end{abstract}

\section{Introduction}

Since the pioneering work by Kawai ${ }^{1)}$ in 1969 , polymer electrets, notably poly(vinylidene fluoride) (PVDF), have caught a great attention as new piezo- and pyroelectric materials. Owing to their flexibility and capability of being used in large area, these materials provide a possibility of new applications which could not be realized with conventional crystallite substance. Therefore many investigators have actively studied to clarify the origin of the piezoelectricity in PVDF.

Recently, Broadhurst et al. ${ }^{2)}$ and Wada et al., ${ }^{3)}$ have proposed the theory in which the piezoelectric constant is described as a function of residual polarization, $P_{\mathrm{r}}$, electrostriction and $\mathrm{di}$ mensional factor (especially poisson's ratio). The piezoelectricity increases with increasing $P_{\mathrm{r}}{ }^{4)}$, electrostriction constant and Poisson's ratio. The magnitude of $P_{\mathbf{r}}$ mainly depends on two factors which are the fraction of Form I crystal and the orientation of dipoles. The electrostriction constant increases with the degree of amorphous orientation $^{5)}$. The last term, Poisson's ratio, is affected not only by the degree of amorphous orientation but also by the crystal anisotropy ${ }^{6}$.
There are several reports on strong piezoelectricity in PVDF films; annealed under high pressure ${ }^{7)}$. stretched during corona charging ${ }^{8)}$, highly oriented ${ }^{9)}$, doubly oriented ${ }^{10) 11)}$ and poled by biased plasma ${ }^{12}$. However, mechanisms of the enhancement of piezoelectricity have not been clarified yet.

In this paper, we report the annealing effect on piezoelectricity and present a new method of electret preparation by which strong piezoelectric film with $d_{31}$ more than $40 \mathrm{pC} / \mathrm{N}$, can be obtained. In particular, we present new evidence that the strong piezoelectricity originates from the facility of dipole rotation induced by poling during the crystal transition.

\section{Experimental}

\section{Sample preparation}

PVDF used in this work was KF 1100 supplied as pellets by Kureha Chemical Industry Co. Unoriented film of $80 \mu \mathrm{m}$ in thickness was obtained by melt-extrusion and then quenched rapidly into ice water. In the annealing experiment, five samples were prepared by drawing and annealing at various temperatures for comparison. Sample (a) was stretched four times of the original length at 
$50^{\circ} \mathrm{C}$. Samples (b) $-(\mathrm{e})$ were also stretched four times at $80^{\circ} \mathrm{C}$ and annealed under the fixed end for $1 \mathrm{hr}$ at $80^{\circ} \mathrm{C}, 110^{\circ} \mathrm{C}, 140^{\circ} \mathrm{C}$ and $170^{\circ} \mathrm{C}$, respectively. Then, aluminum electrodes were evapolated onto both surfaces. A high d.c. electric field was applied to the film at room temperature. The film was heated to $110^{\circ} \mathrm{C}$, and held for 30 minutes, and the field was maintained until the film was cooled down to the room temperature.

Another method of electret preparation was the use of the apparatus of zone-drawing and annealing, as shown in Figure 1. Two knife edged heaters $4 \mathrm{~cm}$ wide attached to the crosshead was insulated from electric circuit by coating with polytetrafluoroethylene (PTFE). The temperature of the heater can be held constant throughout experimental period. A thin and flexible electrode wound on a stick was supplied to the stretched sample with the move of the crosshead. An undrawn film applied with silicone oil on its surfaces was clipped with the electrodes of aluminum foils of $7 \mu \mathrm{m}$ in thickness. The film was zone-drawn and zone-annealed under high electric field. Typi-

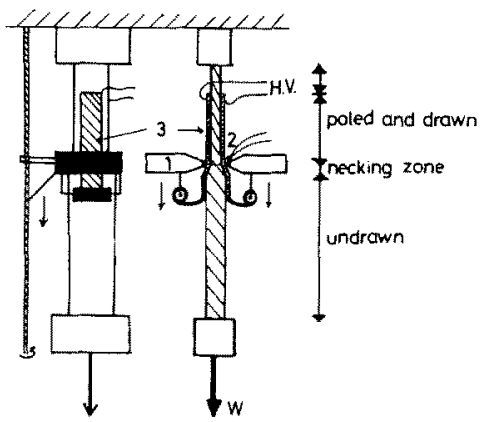

Fig. 1 Detailed representation of the apparatus for zone-drawing under an electric field.

(1; heater, 2; thermocouple, 3 ; aluminum foil electrode.)

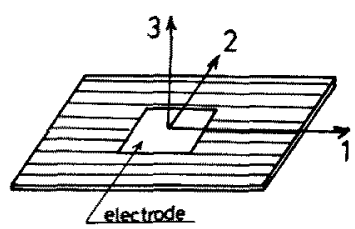

Fig. 2 Geometry of electrode sample and Cartesian coordinate systems assigned. The axis 1 is taken along the stretching direction. cal drawing conditions were as follows: drawing rate, $20 \mathrm{~mm} / \mathrm{min}$; drawing stress, 30MPa. (zoneannealing rate; $20 \mathrm{~mm} / \mathrm{min}$ )

\section{Measurement}

We defined axes 1, 2 and 3 for the film; the axis 1 being parallel to the drawing direction and axes 2 and 3 , normal to the film plane as shown in figure 2. The piezoelectric constants $e_{31}$ and $d_{31}$, which express the polarization in the direction of thickness induced by strain or stress in the direction of the length respectively, were measured by using automatically zero-balancing apparatus ${ }^{13)}$ at $10 \mathrm{~Hz}$. Lattice spacing and diffraction intensity were measured by an X-ray diffractometer (Rigaku Denki Co.; Geiger-flex) with nickel filtered $\mathrm{Cu}-\mathrm{K} \alpha$ radiation. Long period in crystal was measured by small angle $X$-ray scattering.

\section{Results and Discussion}

\section{Annealing effect for stretched samples}

Figure 3 shows piezoelectric constant $e_{31}$ obtained from various samples $(a)-(e)$ as a function of poling field. Here, every sample contains only Form I crystallite. Although $e_{31}$ for all the samples increases almost linearly with increasing

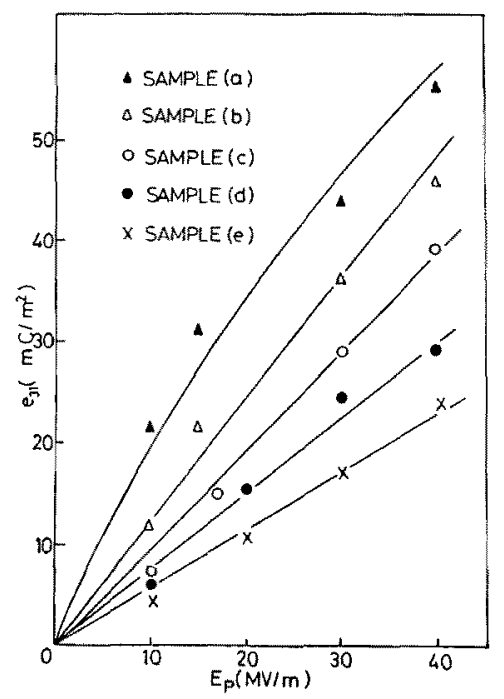

Fig. 3 Plots of piezoelectric constant $e_{31}$ of various samples against poling field strength (poling temperature: $110^{\circ} \mathrm{C}$ )

Annealing Temperature; (a) $50^{\circ} \mathrm{C}$, (b) $80^{\circ} \mathrm{C}$, (c) $110^{\circ} \mathrm{C}$, (d) $140^{\circ} \mathrm{C}$, and (e) $170^{\circ} \mathrm{C}$. 
the poling field, the magnitude for each sample is varied according to the annealing temperature. Effect of simultaneous annealing and poling on piezoelectricity is remarkable; e.g., the magnitude of $e_{31}$ of sample (a) is twice as large as that of sample (e). In order to clarify the differences in piezoelectricity, detailed analysis of the crystal structure was carried out with an X-ray diffraction method.

Figure 4 shows a change of the lattice constant of $(110,200)$ and $(100)$ planes of form I crystals as a function of annealing temperature. With an increase of annealing temperature, the lattice constant of $(110,200)$ plane decreases to approach to an equilibrium value, whereas that of (001) plane is unchanged. Further, the diffraction intensity of $(110,200)$ and $(001)$ planes increase with anneal. ing temperature, which indicates an increase in crystallinity and crystal perfection in their films. However, the crystal and the amorphous chain orientations don't change very much owing to the annealing with fixed end.

Figure 5 shows the effect of annealing tem. perature on a long period calculated from a small angle $x$-ray diffraction pattern. The long period which is an index of crystal thickness increases at higher annealing temperature. The results shown in Figure 4 and 5 clearly point out that the crystal transition of form 11 into form I and that the stabilization of form I crystals occurs during annealing.

The piezoelectric activity in PVDF strongly depends on the magnitude of residual polarization, $P_{r}$, which originates from the dipole orientation. The piezoelectric constant $e_{31}$ is directly proportional to $P_{\mathrm{r}}$. In order to orient the dipoles in form I crystals, it is necessary that the dipoles should rotate around the main chain under the electric field applied. From this point of view, it may be considered that the internal rotation of dipoles occurs more preferentially in the roughly packed crystal lattice than in the tightly packed and thermodynamically stable lattice. This is confirmed by the effect of poling on the intensity of X-ray diffraction.

Figure 6 shows the ratio of X-ray $(400,220)$ intensity of the poled and the unpoled samples by symmetrical reflection method against annealing temperature. At any temperature this ratio of

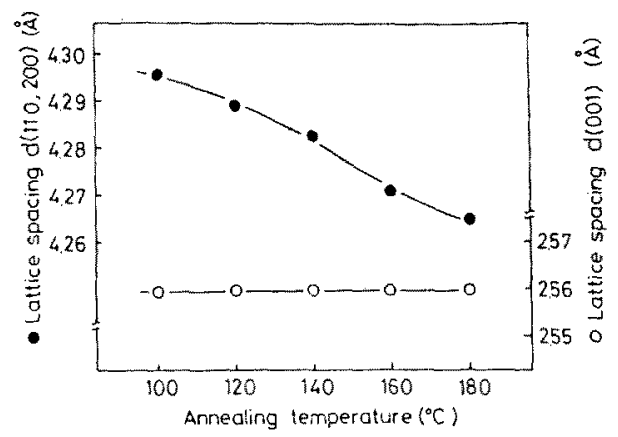

Fig. 4 Plots of lattice spacings of $(110,200)$ and (001) planes against annealing temperature.

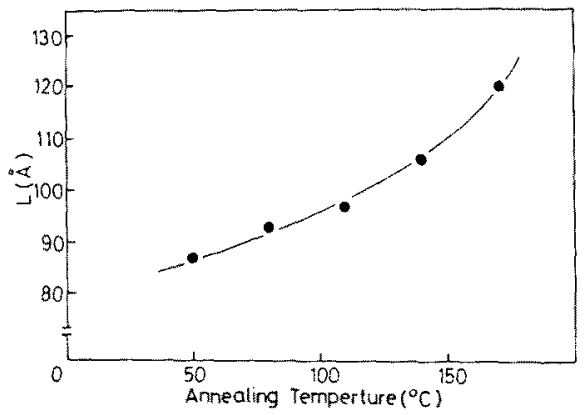

Fig. 5 Plots of long period against annealing temperature.

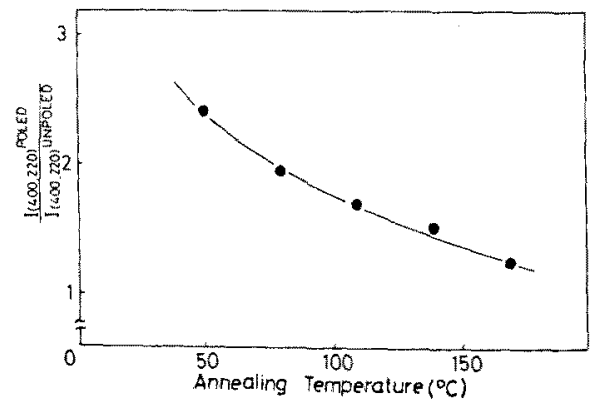

Fig. 6 Plots of the ratio of X-ray intensities for poled and unpoled sample against annealing temperature.

more than unity represents the increase in crystallinity and dipole orientation after poling, and increases with decreasing the annealing temperature. Similar poling effect has been reported by Takahashi et al. ${ }^{14,15}$ ) Moreover, field-induced phase transition from form II to form I has also 
been reported ${ }^{16)}$. Therefore, the sample which is simultaneously poled and annealed after being stretched at low temperature would have large $P_{\mathrm{r}}$ and show strong piezoelectricity as seen in the sample (a). In fact, the sample (a) gives largest depolarization current upon heating. According to this idea, PVDF films stretched and poled simultaneously will show stronger piezoelectric activity than the films poled and annealed simultaneously, since the crystal transformation and the disorder of lattice are more emphasized during stretching.

Simultaneous process of zone-drawing and poling

Zone-drawing ${ }^{17)}$ and zone-annealing ${ }^{18}$ in polymer, developed by Kamezawa et al. and Kunugi et al, respectively, are noted as a new processing technique and can be good methods for making fibers of high modulus and high strength. We applied this technique to improvement of mechanical and electrical properties. Moreover, by using the zone-drawing apparatus modified as shown in Figure 1 , it is possible that the poling field and temperature are applied to a necking zone with crystal transition. The new poling method using the modified apparatus includes simultaneous zone-drawing and poling processes. Therefore, we called this method "zone-poling"

Figure 7 shows the piezoelectric constants, $d_{31}$ and $e_{31}$ of a film zone-pold at $50^{\circ} \mathrm{C}$. Here, poling field strength was calculated from the thickness of sample after necking. Consequently, the necking zone which is the most effective part for dipole rotation is applied by lower electric field than that of stretched part because of the reduction process of thickness. Both constants $d_{31}$ and $e_{31}$ exhibits very large value even at low poling field. As shown in Figure 8, the piezoelectric activity of the films thus prepared changes with drawing and poling temperature and shows the maximum at $50^{\circ} \mathrm{C}-60^{\circ} \mathrm{C}$ which corresponds to the dispersion temperature of form II crystal ${ }^{19)}$. At this dispersion temperature the crystal transformation occurs effectively, so that the dipole will be easily rotated by the electric field applied simultaneously.

Figure 9 shows the effects of zone-annealing on electromechanical coupling constant which represents the efficiency of energy conversion between electrical and mechanical energy for piezoelectrics.

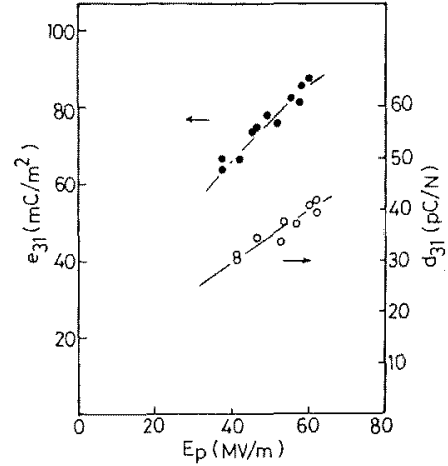

Fig. 7 Plots of piezoelectric constants $e_{31}$ and $d_{31}$ for simultaneously poled and stretched samples against poling field strength.

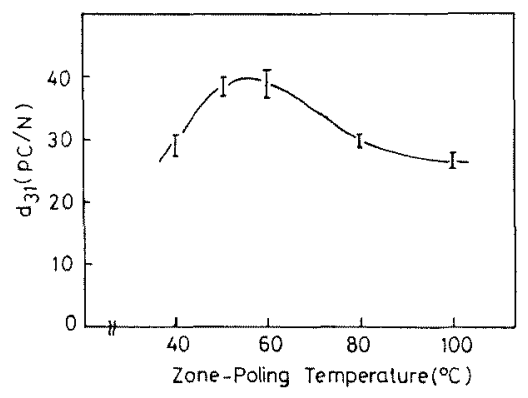

Fig. 8 Plots of piezoelectric constant $d$ against zone-poling temperature.

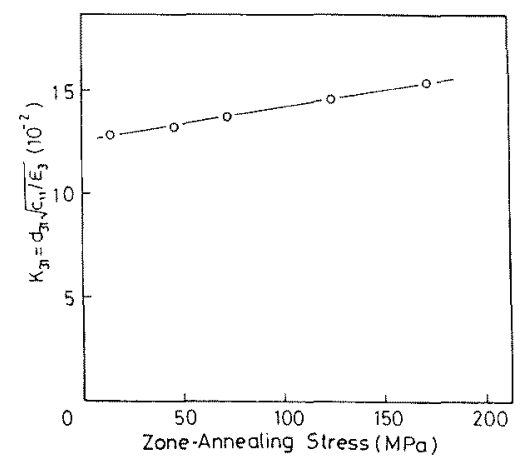

Fig. 9 Plots of electro-mechanical coupling constant $K_{31}$ for simultaneously zone-annealed and poled samples against zone-annealing stress $(\varepsilon$; dielectric constant, $c$; elastic constant). 
Zone-annealing was carried out by moving the cross-head heater up and down for five times under the electric field (crosshead speed; $40 \mathrm{~mm}$ / min). Samples used were zone-poled at $60^{\circ} \mathrm{C}$ (draw ratio $R=3.3$ ) and then zone-annealed $(R=4.2)$. With increasing the zone-annealing stress, the coupling constant increases linearly. This tendency could not be explained only by the improvement of mechanical properties. In the zone-annealing process, therefore, the stretched and poled sample is considered to undergo the dipole orientation more perfectly.

In conclusion, zone-poling is a new method to enhance the piezoelectricity more than $40 \mathrm{pC} / \mathrm{N}$ in PVDF. The piezoelectricity obtained by this method is larger than that of other methods $\left(d_{31}=20-35 \mathrm{pC} / \mathrm{N}\right)$ reported in previous paper $\left.{ }^{8-12}\right)$ Moreover, the method would be applicable to a continuous process by which some polymer electret was industrially manufactured.

\section{Acknowledgement}

This work was partly supported by a Grant in Aid from Ministry of Education in Japan.

\section{References}

1) H. Kawai, Jpn. J. Appl. Phys.. 8, 975 (1969).

2) M, G. Broadhurst, G. T. Davis, J. E. McKinny and R. E. Collin, J. Appl. Phys, 49, 4992 (1978).

3) Y. Wada and R. Hayakawa, Ferroelectrics, 32, 115 (1981).
4) N. Murayama, T. Oikawa, T. Katto and K. Nakamura, J. Polym. Sci. Polym. Phys. Ed., 13,1033 (1975).

5) S. Tasaka and S. Miyata, Kobunshi Ronbunshu, 36, 689 (1979).

6) S. Tasaka and S. Miyata, Ferroelectrics, 32, 17 (1981).

7) S. Miyata, S. Tasaka, Y. Ando, K. Sakaoku and E. Fukada, Extended Abstracts International Workshop on Electric Charges and Dielectrics, 96 (1976).

8) T. Furukawa, T. Goho, M. Date, T. Takamatsu and E. Fukada, Kobunshi Ronbunshu, $36,685\langle 1979\rangle$.

9) E. L. Nix, L. Holt, J. C. McGrath and I. M. Ward, Ferroelectrics, 32, 103 (1981).

10) T. T. Wang, J. Appl. Phys., 50, 6091 (1979).

11) T. T. Wang, J. E. West, J. Appl. Phys., 53, $6552(1982)$.

12) J. E. McKinney, G. T. Davis and M. G. Broadhurst, J. Appl. Phys., 51, 1676 (1980).

13) T. Furukawa and E. Fukada, J. Polym. Sci. Polym. Phys. Ed. 14, 1979 (1976).

14) N. Takahashi and A. Odajima, Rept. Prog. Polym. Phys. Jap., 23, 161 (1980).

15) N. Takahashi and A. Odajima, Ferroelectrics, 32, 49 (1981).

16) R. G. Kepler and R. A. Anderson, J. Appl, Phys, 49, 1232 (1978).

17) K. Kamezawa, K. Yamada and M. Takayanagi, J. Appl. Polym. Sci., 24, 1227 (1979).

18) T. Kunugi, A. Suzuki and M. Hashimoto, J. Appl. Polym. Sci., 26, 213 (1981).

19) H. Sasabe, S. Saito, M. Asahina and H. Kakutani, J. Polym. Sci., A-2, 7, 1405 (1969).

延伸・分極同時処理したポリフッ化ビニリデンの高圧電性

\author{
東京農工大学工学部田坂 茂，白石克已，村上和朋，宮田清蔵
}

延伸したポリつッ化ビニリデン瞙を各温度で熱処理し， その正電特性を調へた。熱処理温度の上昇と上もに，結 晶性は向上，，I 型結晶 $(110,200)$ 面の格子定数は小 さくなり，結晶の完全性枯向上した。しかしながら，压 電栍は，結晶の完全性之は逆倸小さく，結晶双極子の配

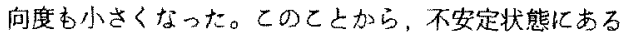
結晶に電界を印加すれぱ，C-F 双極子を最も有効に配
向させることが可能であると予想される。

この原理に㫷づき，新しい分極法を提案した。すなる

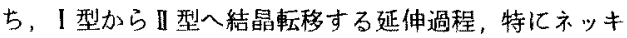
ングゾーンにのみ大きな電啰を印加する延伸，分極同時 処理であり，ゾーン延伸の手法を改良して行った。得ら れた代電率は，比較的低い電界好理です $d_{91} \sim 40 \mathrm{pC} / \mathrm{N}$ と非常に大きな値を得ることができた。 